\title{
LOW BIRTHWEIGHT, PRETERM BIRTH, AND THEIR ASSOCIATIONS WITH THE RISK OF ASPHYXIA
}

\author{
Yustina Purwaningsih'), Yulia Lanti Retno Dewi'), \\ Dono Indarto3), Bhisma Murti1) \\ ${ }^{1)}$ Masters Program in Public Health, Universitas Sebelas Maret \\ 2)Department of Nutrition, Faculty of Medicine, Universitas Sebelas Maret \\ 3)Faculty of Medicine, Universitas Sebelas Maret
}

\begin{abstract}
Background: Perinatal asphyxia, neonatal asphyxia, or birth asphyxia has been defined as the medical condition resulting from deprivation of oxygen to a newborn infant that lasts long enough during the birth process to cause physical harm, usually to the brain. If left untreated, neonatal asphyxia can cause a severe lack of oxygen to the baby's brain, which can injure brain cells and cause hypoxicischemic encephalopathy (HIE), cerebral palsy, seizures, and other forms of brain damage. This study aimed to examine the association between low birthweight, preterm birth, and the risk of asphyxia.
\end{abstract}

Subjects and Method: This was an analytic observational study with a case control design. The study was conducted at the perinatology ward, Dr. Harjono Hospital, Ponorogo, East Java, in July 2018. A sample data of 360 newly born infants between January 2017 and December 2017 was selected for this study by fixed disease sampling, consisting of 180 newborns with asphyxia and 180 newborns without asphyxia. The dependent variable was birth asphyxia. The independent variables were low birthweight and prematurity. The secondary data were obtained from the medical record and analyzed by a multiple logistic regression.

Results: Asphyxia was associated with low birthweight $(\mathrm{OR}=4.16 ; 95 \% \mathrm{CI}=2.04$ to $8.49 ; \mathrm{p}<0.001)$ and prematurity $(\mathrm{OR}=4.05 ; 95 \% \mathrm{CI}=2.05$ to $8.03 ; \mathrm{p}<0.001)$.

Conclusion: Asphyxia is associated with low birthweight and prematurity.

Keywords: asphyxia, low birthweight, prematurity

\section{Correspondence:}

Yustina Purwaningsih. Masters Program in Public Health, Universitas Sebelas Maret, Jl. Ir. Sutami No. 36 A, Surakarta 57126, Central Java.

Email: yustinapurwaningsih202@gmail.com 